Issues in Information Systems

Volume 18, Issue 2, pp. 31-38, 2017

\title{
INTEGRATED CONTROL MECHANISMS TOWARD PROJECT MANAGEMENT SUCCESS
}

\author{
Ganesh Vaidyanathan, Indiana University South Bend, gvaidyan@iusb.edu
}

\begin{abstract}
In recent years, project management factors that lead to project success has been the subject of discussion. Successful project management methods lead to the success of projects. Information Systems (IS) project management has been lauded for many of its successes as well as criticized for some of its failures. Project management in firms has been under constant scrutiny in order to determine project success and failures. There have been a number of research articles, both theoretical and empirical, to determine the success factors of project management. As different methods to implement information technology projects evolved, project managers had to change their ways to bring their projects to fruition. In this process of change, success criteria for project management have changed over the years. This paper redefines success factors of project management towards the success of IS projects by establishing a framework that consists of seven dimensions.
\end{abstract}

Keywords: Information Systems (IS), Information Technology (IT), Project, Project Management, Success Factors

\section{INTRODUCTION}

Project success has been a topic in project management literature for a long period of time (Brown \& Adams, 2000; Serra \& Kunc, 2015). Success and failure of projects depend upon completion of a project within scope or customer requirements, within the allocated budget, within the allocated schedule or period of time, with established performance standards and technology usage, and with a focus to maximize the project value for stakeholders (Vaidyanathan, 2013). Successful project management demands monitoring, controlling, and managing several project related variables. Moreover, there are many internal as well as external elements to enable a successful project. Although related, there is a distinction between project management success and project success (Baccarini, 1999; Cooke-Davies, 2002). While project success deals with the success of final project objectives, project management success has been debated (Pheng \& Chuan, 2006; Vaidyanathan, 2013). Shenhar et al. (1997) argued that project management success is an internal measure of the efficiency of a project but project success is related to the external effectiveness resulting from the project. Wite (1988) determined that good project management contributes towards project success but is unlikely to be able to prevent project failure. Therefore, the art and science of project management methodologies are an important aspect of project success or failures.

Project failures have been identified and researched in the literature through the years. Small projects are easier to manage and execute. A recent Gartner report (Mieritz, 2012) conveyed that failure rate of large IS projects with budgets exceeding $\$ 1$ million was found to be almost 50\% higher than for projects with budgets below $\$ 350,000$. Scholars have identified the following factors for project failures (Kerzner, 2006; Cash \& Fox, 1992; Wite, 1988; Kumar, 1989):

- Functionality issues;

- Quality issues;

- High cost and schedule variance;

- Canceled after launch;

- Rejected or not implemented for other reasons;

- Relations with the customers and other stakeholders;

- Contracts and legal agreements;

- Insufficient resources;

- Politics and conflicts;

- Unrealistic goals; 
- Poor communication;

- Competitive disadvantage;

- Customer dissatisfaction; and

- Perceived value of the project.

Project management plays a role in project success and failure but that role is affected by many other factors outside the direct control of the project manager (Munns \& Bjeirmi, 1996). Therefore, even if the project management process is a success in a firm, the accomplished project may be perceived as a failure. Such factors that may cause project management to fail include:

- Inadequate rationale set before project charter;

- Selection of wrong project manager;

- Unsupportive top management;

- Lack or misuse of project management techniques; and

- Lack of commitment by project champion and organization.

Project management has evolved as a subject deeply rooted in operations management, IS, and finance. Most organizations use project management as a tool to manage their projects and improve productivity. It is estimated that between 2010 and 2020, 15.7 million new project management roles will be created globally, and the project management industry is slated to grow by $\$ 6.61$ trillion (PMI, 2013). Although scholars have identified many factors that a project manager can and should control to prevent project failures in the form of project management, Mir \& Pinnington (2014) point out that there is an insufficient understanding of the relationships between project management performance and project success. They summarize that there is a continuing need for clear understanding of project management criteria that are essential to project success (Mir \& Pinnington, 2014). Furthermore, Gan et al., (2015) stressed that context-specific critical success factors need to be developed to assist project managers.

This paper focuses on project management performance variables that are pertinent to project success to establish a framework. The analysis of this framework illustrates the relationship between project management performance and project success. The next section of this paper describes project management implementation process in organizations. The following section describes an integrated control of projects through a project management process. Using the control variables, a framework of project management control mechanisms is proposed with an analysis. The last section draws the conclusion and future research.

\section{PROJECT MANAGEMENT}

Project success and project management success are different. Project success deals with the impacts of a project's final product on stakeholders. Project management success focuses on the processes of a project including successful control of cost, time, and quality (Baccarini, 1999). Performance of a project is usually measured by quality as a success criterion.

Project management consists of many components. Although each project is unique, has a set of unique goals, performed by different people with different cultures and value, implemented in different parts of the globe by different organizations, all projects have a common theme with same set of components. For projects to be successful, the foundation is, of course, strategy, leadership, and management. Project management in industries practice such fundamental components. Project management components used to realize project success include:

- A clear definition of the project including good rationale and alignment to corporate goals;

- Developing a project organizational structure with associated channels of communication, accountabilities, responsibilities, and reporting facilities;

- Defining project requirements from customers and establishing a project scope for success;

- Planning the project to include analysis of activities, defining and developing major tasks with milestones;

- Estimating time, costs, resource requirements and defining performance measures, project value;

- Scheduling all activities; 
- Continuously monitoring and controlling scope, time, cost, performance factors, and project value;

- Implementing the project;

- Bringing closure to a successful project; and

- Creating and benefiting from project value.

Project management encompass both the art and science of management. They also include the technical and sociocultural aspects of technology, communication, teamwork, and other organizational management factors.

Successful companies tend to use established project management processes and techniques. Successful project management requires accomplished project managers, great planning techniques, resources, commitment, and good communication. Projects are managed by using the right tools, processes, techniques and resources without adversely disturbing the operations of an organization. Such activities help project managers understand project tasks, assign resources, plan and implement projects, and eventually avoid project failures. Inadequate rationale, misunderstood objectives, wrong project manager, unsupportive top management, lack or misuse of project management techniques, inadequate project planning, and lack of commitment to the project may cause project management to fail. However, some of these factors are outside the direct control of the project manager (Munns \& Bjeirmi, 1996).

Projects are implemented under certain constraints and those constraints become an important part of the success or failure of projects. Success of a project depends upon controlling and managing such constraints. Three constraints that include scope, time, and cost have been used extensively in many industries (McGhee \& McAliney, 2007). Scope and performance are also important aspects of project management control (Kerzner, 2006). Another constraint, customer satisfaction, has been proposed as well (Kerzner, 2006) but that is beyond the control of project managers. Controlling and managing the restructured components of resources of an organization and leveraging on their capabilities provides value (Sirmon, Hitt, \& Ireland, 2002). A major factor of project failure is project risk management (Kerzner, 2006). In summary, project management is the act of collaborating with people using required resources, such that a project is planned, organized, and controlled effectively to accomplish the project goals and the objectives (Vaidyanathan, 2013).

The components of project management that are used to realize project success starts with a clear definition of the project, including good rationale and alignment to corporate goals. The clear definition should lead to identifying and gathering project requirements from stakeholders and establishing a project scope for project success. Using the scope, a project is planned in the existing organizational structure with associated channels of communication, accountability, responsibility, and reporting. The planning includes all facets of the project management including scope, cost, schedule, resources, performance or quality, risks, communication, and procurement. Costs, schedule, resource requirements, performance measures, and project value needs to be estimated, monitored, and controlled. Risks are identified, evaluated, and mitigated at every stage of a project. Although there are many qualitative and quantitative failure factors with project management, the major component of project failure is project risk management (Kerzner, 2006). Risks due to technology, finance, and environmental/market/political/legal issues have to accessed, analyzed, mitigated, controlled, and managed to ensure smooth implementation and success of projects.

\section{INTEGRATED CONTROL OF PROJECT PERFORMANCE FACTORS}

The time difference between monitoring and control result in late identification of deviations in the performance of projects. The deviations lead to late corrective actions that result in cost and schedule overruns. A continuous evaluation of various project performance factors is required to monitor and control projects to avoid such overruns. Earned value management factors such as planned value, earned value and actual cost aggregates the progress of task activities to provide the pulse of the project. Those three factors identify project performance in terms of cost and schedule to the project managers for corrective actions.

Monitoring and controlling of project work is a process of tracking, evaluating, and changing the performance factors of the progress of a project to meet the performance objectives defined in the project management plan (PMBOK, 2008). Collection, measurement, and analysis of important information on performance factors throughout the length 
of a project constitutes monitoring of projects. The monitoring and controlling of a project includes following tasks (PMBOK, 2008):

- Comparing project factors such as scope, cost, schedule, resources, performance, values against the project management plan;

- Identifying, analyzing, tracking, monitoring, and managing risks;

- Assessing project quality and implementing corrective and preventive actions as necessary;

- Forecasting changes in project costs, resource allocations, and schedules; and

- Implementing approved changes.

A continuous monitoring of key factors of a project provides the project team insight in a project. The monitoring activity identifies the key areas of a project that require additional attention. Corrective actions and preventive measures can steer a project toward success. According to PMBOK (2008), the inputs of the project control include success factors. The outputs of proper project control are change requests, project status updates, project management plan updates, project document updates, and actual changes to the project implementation.

\section{FRAMEWORK FOR PROJECT MANAGEMENT SUCCESS}

Asad \& Pinnington (2014) observed that the key performance indicators to be the most significant variable contributing towards the success of any project. Such key performance indicators of project management include factors that show results achieved in relation to meeting the requirements of project stakeholders and some of the methodologies used to improve project management performance. We have chosen such key factors that play a vital role in the integrated control of a project as the factors of project management success. A project manager should have direct control of these success factors.

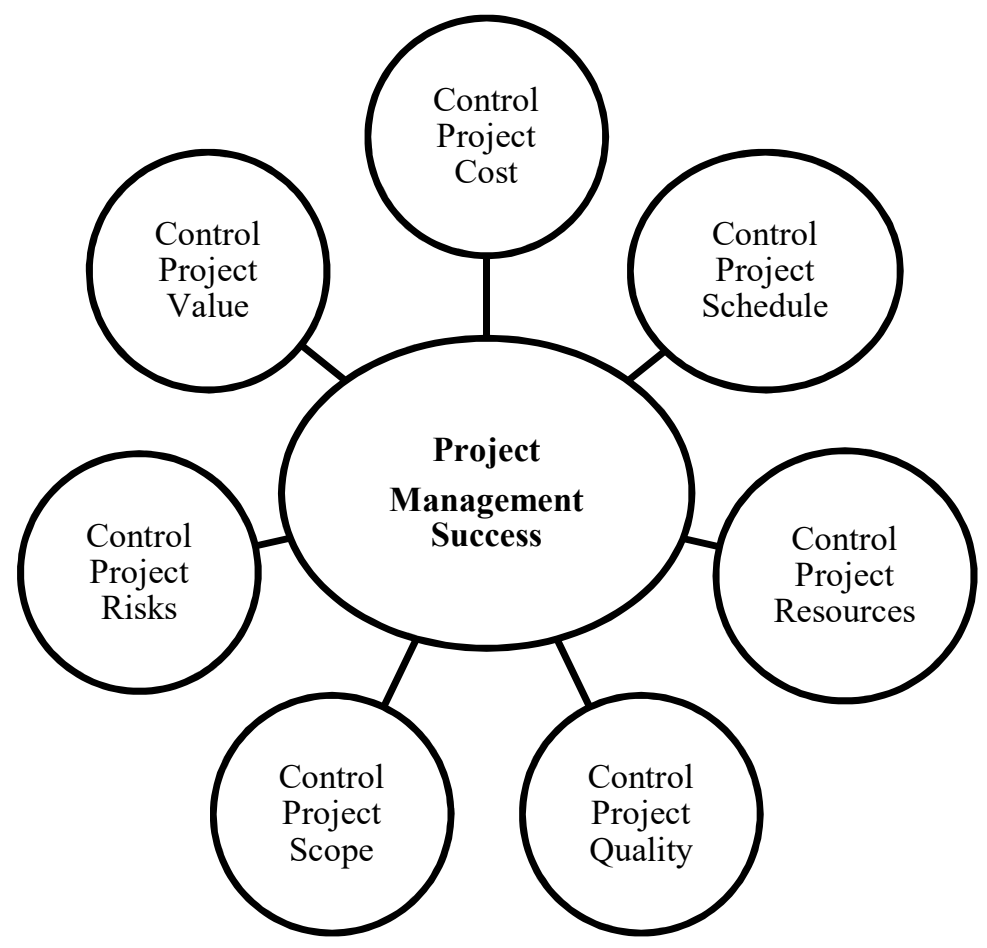

Figure 1. Project Management Success Factors 
The factors that influence stakeholder requirements include planned value, actual cost, earned value, cost variance, cost performance index, schedule variance, schedule performance index, overdue project tasks, missed milestones, percentage of tasks completed on time, and resource utilization. These factors are included in cost, schedule, and resources. Figure 1 illustrates the project success factors.

The project has costs that include tangible or intangible, direct or indirect, or sunk. Tangible costs are quantifiable cost related to an identifiable resource or asset. Intangible costs may be losses in productivity, customer goodwill or drops in employee morale. Direct costs are directly traced to producing products, systems, or services. Indirect costs are costs that are incurred for common or joint objectives and therefore cannot be identified readily and specifically with a project. A sunk cost is an expense that cannot be recovered. The cost management processes includes cost estimating, budgeting, cost control, and resource planning.

Another key part of project management is the schedule. A schedule describes various activities in a project such as the start and end times of each activity, the number of activities completed at a given time, and the sequence of implementation of those activities. A regular revision of a project schedule is necessary as the project progresses through time. The schedule provides a basis to monitor and control project activities and helps the project manager to determine time delays that may affect a project. Resources are central to project success. A resource must enable an organization to create value by either outperforming its competitors or reduce its own weaknesses. A resource must be valuable, rare, in-imitable, and non-substitutable (Barney, 1991). Resources are tradable and non-specific to the firm, while capabilities are firm-specific and used to utilize the resources within the firm, such as implicit processes to transfer knowledge within the firm (Hoopes, Madsen, \& Walker, 2003). Resources of an organization include all assets, capabilities, processes, attributes, and knowledge to name a few. Such resources might be in the form of humans, computers, processes, collective knowledge, cash, etc.

Scope describes the base requirements of customers along with organizational requirements. The scope is a constraint and it refers to what is required for the project's result. The performance of a project depends on many factors including quality of the result, knowledge within organizational workers, knowledge accumulated by previous experiences or past projects, organizational processes containing some of the knowledge, and technology used in the project. Value recognized by organizations includes customer as well as stakeholder satisfaction. Risk is in many ways. In addition, creation of new markets, return on investment, and profitability gained by a project must be included as important parameters of value creation. The overall success factor of a project is the realized value of the project that can be measured by the project stakeholders.

Risk is a function of the likelihood of a given threat and the resulting impact of that adverse event on the organization (Kwak \& La Place, 2005). A project risk is an uncertain event and if that event occurs there will be a positive or negative effect on the objectives of the project (PMBOK, 2008). Risk management is the process that allows project managers to balance the operational and economic costs of protective measures and achieve project success. A wellstructured risk management methodology when used effectively can help project managers identify appropriate controls to monitor and mitigate project risks. Managing project risks is important in prioritizing risks, addressing the most crucial ones, and reducing such risks so that the overall risk of a project is acceptable.

A project manager should control a project within the scope or customer requirements, within cost, within time, within performance standards set by stakeholders, managing risks, and maximizing stakeholder value. These seven factors are shown in Figure 1. Table 1 shows the impacts of the seven factors on project success. 
Table 1. Impact of seven factors on project management success

\begin{tabular}{|l|l|}
\hline Factors & Impacts \\
\hline Scope & $\begin{array}{l}\text { Increase in scope can lead to increase in time, increase in cost, better } \\
\text { or worse quality, increase in resources, increase or decrease in value }\end{array}$ \\
\hline Time & $\begin{array}{l}\text { Tight time constraint can lead to increase in cost, reduced scope, } \\
\text { reduced performance, increase in resources, and reduced value }\end{array}$ \\
\hline Cost & $\begin{array}{l}\text { Tight budget constraint can lead to increased time, reduced scope, } \\
\text { reduced performance, increase or decrease in resources, and reduced } \\
\text { value }\end{array}$ \\
\hline Resources & $\begin{array}{l}\text { Unskilled, less, faulty, bad quality resources lead to increased time, } \\
\text { reduced performance, reduced value, higher costs, and short of scope }\end{array}$ \\
\hline Performance & $\begin{array}{l}\text { Stringent performance measures can lead to increased time, increased } \\
\text { scope, increased cost, increase or decrease in resources, and increase } \\
\text { or decrease in value }\end{array}$ \\
\hline Value & $\begin{array}{l}\text { Expected value measures can lead to increased scope, increased time, } \\
\text { increased cost, demand for better or more resources, and better or } \\
\text { worse performance }\end{array}$ \\
\hline & $\begin{array}{l}\text { Risks encountered in projects can increase costs, impact schedule, } \\
\text { demand more resources, undermine value, degrade performance, and } \\
\text { create difficulty in controlling scope }\end{array}$ \\
\hline
\end{tabular}

The following factors and constraints affect either the success or failure of projects:

- Completion of project within scope or customer requirements;

- Completion of project within allocated budget;

- Completion of project within allocated schedule or period of time;

- Completion of project using allocated resources;

- Completion of project within established performance and technology standards;

- Completion of project to maximize project value for stakeholders; and

- Completion of project by managing risks.

\section{CONCLUSION AND FUTURE RESEARCH}

Badewi (2016) summarized that project management practices influence both project success and project investment success. Effective control of projects require project managers to identify problems with respect to budget, schedule, resources, quality, scope creep, project devaluation, and risks. This paper illustrates success factors of project management towards the success of IS projects by establishing a framework that consists of seven dimensions. The framework described in this paper provides the validity of those important factors of project management. We plan to expand this analysis further in future studies to understand and analyze the relationships between scope, value, resources, cost, time, risk and performance with more specific cases from various industries. Future studies based on this paper may include conducting an empirical analysis of the seven factors on project management performance. 


\section{REFERENCES}

Baccarini, D. (1999). The logical framework method for defining project success. Project Management Journal, $30(4), 25-32$.

Badewi, A. (2016). The impact of project management and benefits management practices on project success: Towards developing a project benefits governance framework. International Journal of Project Management, 34(4), 761-778.

Barney, J. (1991). Firm resources and sustained competitive advantage. Journal of Management, 17 (1), 99-120.

Brown, A., \& Adams, J. (2000). Measuring the effect of project management on construction outputs: a new approach. International Journal of Project Management, 18, 327-335.

Cash, H., \& Fox, R. (1992). Elements of successful project management. Journal of Systems Management, 49(3), $10-12$.

Cooke-Davies, T. (2002). The "real" success factors on projects. International Journal of Project Management, 20, $185-190$.

Gan, X., Zuo, J., Ye, K., Skitmore, M., \& Xiong, B., (2015). Why sustainable construction? Why not? An owner's perspective. Habitat Int. 47, 61-68.

Hoopes, D., Madsen, T., \& Walker, G. (2003). Why is there a Resource-Based View? Toward a Theory of Competitive Heterogeneity. Strategic Management Journal, 24 (10).

Mir, F.A., \& Pinnington, A.H. (2014). Exploring the value of project management: Linking Project Management Performance and Project Success. International Journal of Project Management, 32, 202-217.

Kerzner, H. (2006). Project management: A systems approach to planning, scheduling, and controlling. Ninth Edition. Hoboken, NJ: John Wiley \& Sons.

Kumar, D. (1989). Developing strategies and philosophies early for successful project implementation. Project Management, 7(3), 164-171.

Kwak, Y.H., \& La Place, K.S. (2005). Technovation, 25, 691-695.

McGhee, P., \& McAliney, P. (2007). Painless Project Management. Hoboken, NJ: John Wiley \& Sons.

Mieritz, L. (2012). Gartner Survey Shows Why Projects Fail. Accessed at https://thisiswhatgoodlookslike. com/2012/06/10/gartner-survey-shows-why-projects-fail/ on April 6, 2017.

Munns, A., \& Bjeirmi, B. F. (1996). The role of project management in achieving project success. International Journal of Project Management, 14(2), 81-87.

Pheng, L., \& Chuan, Q. (2006). Environmental factors and work performance of project managers in the construction industry. International Journal of Project Management, 24, $24-37$.

PMBOK (2008). A Guide to Project Management Body of Knowledge. Fourth Edition, Newtown Square, PA: Project Management Institute.

PMI. (2013). Project Management between $2010+2020$. Project Management Institute, Pittsburgh, PA: PMI Institute. 
Serra, C.E.M., \& Kunc, M. (2015). Benefits realization management and its influence on project success and on the execution of business strategies. International Journal of Project Management, 133, 53-66.

Shenhar, A., Dvir, D., \& Levy, O. (1997). Mapping the dimensions of project success. Project Management Journal, $28(2), 5-13$.

Sirmon, D., Hitt, M., \& Ireland, R. D. (2002). Managing firm resources in dynamic environments to create value: Looking inside the black box. Academy of Management Review, 32(1), 273-292.

Thomas, J., \& Mullaly, M. (2009). Explorations of value: perspective on the value of project management. Project Management Journal, 40(1), 2-4.

Vaidyanathan, G. (2013). Project management: process, technology, and practice. Upper Saddle River, NJ: Pearson.

Wite, A. D. (1988). Measurement of project success. Project Management, 6(3), 164-170. 